\title{
Políticas editoriais
}

\author{
Harley E. A. Bicas
}

O perfil de uma publicação periódica identifica-a como de linha pedagógica quando ela privilegiar a difusão, a consolidação e o aprofundamento da ciência já adquirida, ou como de linha investigativa se se voltar à apresentação de novos aspectos do conhecimento. Eventualmente, ainda, pode servir a essas duas funções, com mais ou menos ênfase em uma delas. Um desses enquadramentos com que o órgão científico é produzido, determina-se por suas políticas editoriais.

São vários, porém, os fatores que influem na tomada de decisões sobre o direcionamento da publicação. O primeiro e mais importante é o do padrão de oferta das matérias. Reapresentações de assuntos já publicados são, obviamente, de obtenção menos difícil do que os de produção original. Mesmo assim, todavia, reescrever para atender ao que se pode considerar um adequado artigo de revisão, ou de atualização, requer redatores com capacidade de discernimento sobre o que importa apresentar, síntese na elaboração da matéria e boa linguagem. Essa visão abrangente de conhecimentos sobre um certo assunto, a competência para estruturá-lo e desenvolvê-lo com capacidade crítica e expositiva, não são condições facilmente disponíveis: freqüentemente pessoas têm algumas delas, mas não todas, o que faz a diferença.

Artigos originais, por outro lado, não dependem de acasos, nem da vontade de descobrir algo, mas de uma sólida formação acadêmica para a pesquisa e de meios adequados para pô-la em prática. Essa configuração, por sua vez, faz parte de uma complexa rede de apoio à ciência: centros formativos (escolas de pós-graduação; em Oftalmologia apenas cinco em nosso país, duas delas enfrentando sérias dificuldades para sobrevivência), linhas de fomento por universidades e agências financiadoras de bolsas, aquisição de instrumentos, desenvolvimento de métodos (FINEP, CNPq, CAPES e fundações estaduais de amparo à pesquisa, como a FAPESP), ou empresas particulares. Obviamente, a sustentação dessa rede de ciência e tecnologia é vulnerável a decisões governamentais sobre a alocação de verbas que lhe pode ser destinada. E todos sabemos das enormes demandas de desenvolvimento de áreas sociais e outras, em nosso país, competindo por recursos orçamentários. Não obstante, progressivamente, vem se notando o delineamento de um conjunto cada vez maior de autores científicos, cujos estudos dão base ao aprimoramento qualitativo de nossa revista. Naturalmente, isso é fruto da crescente agregação de oftalmologistas no Brasil, do conseqüente maior número de mestres e doutores e representa o lado bom da elevada quantidade de nossas escolas médicas. Enfim, existe já uma oferta nacional de matérias científicas que garante a possibilidade de examiná-las criticamente, com apuro cada vez maior.

Aliás, um segundo fator a influenciar a decisão sobre o perfil de um periódico científico é, precisamente, o do rigor a ser assumido nos filtros de seleção das matérias publicáveis. É claro que não se trata, simplesmente, de separar trabalhos "mal feitos" de "bem feitos". Entre estes há informações em vários níveis ou categorias, o que já provoca uma dúvida a editores: é apenas com um critério probabilístico sobre o efeito de um artigo que se pode considerá-lo como publicável? De fato, as informações de um artigo científico "periférico" podem juntar-se ao acervo de conhecimentos como, apenas, dados marginais; mas, alternativamente, tornar-se importantes para a elaboração de um "nuclear".

É na raiz desse rigor que se pode buscar um "fator de impacto" maior (o que também supõe uma visibilidade maior do periódico, para a qual contribui a língua em que seus conteúdos são apresentados), ou criar oportunidades de crescimento a autores, incentivando-os. Quase que, como para a matrícula de um aluno numa escola, erigir-lhe critérios muito discriminatórios ou possibilitar-lhe o acesso mais fácil. Obviamente um dado de política editorial.

A conciliação é difícil. Alunos intelectualmente diferenciados muito provavelmente optariam por freqüentar uma instituição elitizada. No caso dos periódicos, autores preferem um com maior visibilidade e maior impacto, o que supõe, preferencialmente, apresentação dos conteúdos em inglês e com majoração tanto do nível de exigibilidade quanto da taxa de rejeição dos artigos que lhe são enviados. Infelizmente a adoção desses critérios não é garantia de que maiores impactos sejam gerados e, por outro lado, sacrificam, necessariamente, o contingente "não acadêmico" de seus leitores. Faz contraponto a essa postura exclusivamente academicista o fator das demandas, ou seja, do público leitor de um lado e da literatura científica emergente de outro, sem que ocorram prejuízos da qualidade da publicação. Daí resulta que um contingente cada vez mais numeroso de autores bem diferenciados tem preferido, patrioticamente, publicar nos A.B.O., garantindo os ótimos conceitos com que a revista é reputada.

Finalmente, e apesar do progressivo aumento do número de artigos não aceitos, vem crescendo o dos aprovados para publicação. Poucos talvez tenham se dado conta de que em cada fascículo publicado têm aparecido mais trabalhos. Em 2000 e 2001, os volumes 63 e 64 tiveram 532 e 610 páginas, com 86 e 102 títulos publicados (exceto editoriais). Já em 2002 
(volume 65) tais quantidades, foram, respectivamente, 706 e 111. Felizmente, continua crescente a pressão de demanda dos autores, trazendo um problema com uma de três soluções possíveis: a de aumentar a paginação de cada fascículo (providência já adotada e para a qual ainda há espaço); a de passagem da periodicidade dos A.B.O. de bimensal a mensal (uma alternativa volumetricamente equivalente e que agiliza o aparecimento das publicações, mas trazendo mais trabalhos e despesas); e a de arrocho no processo de seleção, o que de certo modo remete os A.B.O. a um caráter mais acadêmico e elitizado.
Os Editores, Chefe e Associados, são agentes executivos de políticas editoriais delineadas pelo Conselho Administrativo dos A.B.O. Por outro lado e embora autônomo na formulação de suas políticas, esse órgão tem a aplicabilidade de suas decisões jungida às disponibilidades orçamentárias do Conselho Brasileiro de Oftalmologia, o mantenedor efetivo dos A.B.O.

Afinal é assim, também, de que depende a própria ciência: não apenas de idéias, mas de quem financie suas realizações. No fundo, sempre, uma decisão política. 